\title{
POSSIBLE SIDE-REACTIONS WITH DIAZOCARBONYL DIPEPTIDE ESTERS AS PROTEIN MODIFYING REAGENTS
}

by

\author{
FRED WIDMER and THAMMAIAH VISWANATHA
}

Department of Chemistry, University of Waterloo

Waterloo, Ontario, Canada N2L 3G I

and

Department of Chemistry, Carlsberg Laboratory

Gamle Carlsberg Vej 10, DK-2500 Copenhagen Valby

Keywords: Diazocarbonyl compounds, chymotrypsinogen, chymotrypsin, protein modification

\begin{abstract}
The reaction of diazocarbonyl compounds with chymotrypsinogen and chymotrypsin in the presence of cupric ions was accompanied by the oxidative destruction of tryptophan and methionine residues and to a lesser extent of tyrosine and cystine residues of the proteins. $\mathrm{Cu} 2+/$ diazoacetyl-DL-norleucine methyl ester complex was found to promote the oxidation of cystine residues of the proteins while the similar complex with the L-isomer of the diazocarbonyl compound was ineffective. Inclusion of $\alpha$-aminocarbonyl compounds in the reaction medium not only prevented the $\mathrm{Cu}^{2}+$ ion mediated decomposition responsible for the diminution in the potency of the diazocarbonyl compound as a modifying agent, but also permitted the reaction to be accomplished over the $\mathrm{pH}$ range of 4.5 to 7.0 . The side reactions, namely the oxidative destruction of amino acids could be minimized by exclusion of oxygen from the reaction medium.
\end{abstract}

\section{INTRODUCTION}

Diazocarbonyl compounds have found wide application in enzymology. These compounds serve as photoaffinity labels in photochemical reactions $(3,5)$ and as modifiers of nucleophilic side chains of amino acid residues of proteins in dark reactions $(15,18)$. Thus, 6-diazo-5-oxo-Lnorleucine (16) and azaserine (7) were found to interact with a cysteinyl sulfhydryl group of phosphoribosyl pyrophosphate amido trans-

Abbreviations: $\mathrm{DAG}=\alpha$-diazoacetylglycine ethyl ester; DL-DAN $=\alpha$-diazoacetyl-DL-norleucine methyl ester; L-DAN $=\alpha$-diazoacetyl-L-norleucine methyl ester; TLC $=$ thin layer chromatography. All other abbreviations of amino acids, amino acid derivatives and peptides are according to the guidelines of the IUPAC-IUB Commission on Biochemical Nomenclature (for a compilation see ref. 44). 
ferase and 2-formamido- $\mathrm{N}$-ribosylacetamide-5:phosphate: L-glutamine amido ligase, respectively. Most of the published work, however, concerns the modification of carboxyl groups. For example, diazoacetylglycine amide has been employed to modify a reactive aspartic acid residue in ribonuclease (30). The reaction of diazoacetamide with carboxyl residues of chymotrypsinogen and those of model compounds (9), as well as the interaction of diphenyldiazomethane with carboxyl groups of chymotrypsin and its precursor have been documented (1). The reaction of diazocarbonyl compounds with the functional groups of amino acid side chains is normally slow, but is considerably enhanced in the presence of $\mathrm{Cu}^{2+}$ ions. These observations are consistent with the well documented catalytic effect of elemental copper and $\mathrm{Cu}^{2+}$ ions on the reactions of diazoketone-derived carbonyl carbenes $(28,46)$. The reaction of several diazocarbonyl compounds with pepsin in the presence of $\mathrm{Cu}^{2+}$ ions $(6,13)$ provided the basis for the implication of essential carboxyl groups in the active site of this acid protease. Some of these reagents possessed substrate-like structural features, e.g. 1-diazo-4-phenyl-2-butanone (14) and L-1-diazo-4-phenyl-3-tosylamido-butanone (8), rendering them specific to functional groups at the active site. Other reagents, such as diazoacetylglycine ethyl ester and diazoacetic acid ester (reviewed in ref. 37) were found to be much less specific, but nevertheless helped to furnish useful information pertaining to the functional groups involved in pepsin catalysis. The unique requirement of $\mathrm{Cu}^{2}+$ ions for reactions of these reagents with pepsin and other acid proteases $(2,8,20$, $23,24,25,27,29,37-41)$ has been a recognized fact. Thus, inactivation by $\mathrm{Cu}^{2+} /$ diazocarbonyl compounds (in particular by $\mathrm{Cu}^{2+} /$ diazoacetylDL-norleucine methyl ester), as well as by 1,2epoxy-3-(p-nitrophenoxy)-propane (40), has been used as a criterion for the classification of a hydrolytic enzyme as an acid protease. However, in view of the well known high general chemical reactivity of diazoketone-derived carbonyl carbenes $(28,46)$ it appeared important to elucidate any non-specific modifications that might occur as a result of the interaction of $\mathrm{Cu}^{2+} /$ diazocarbonyl complexes with proteins. The current study is concerned with the identification of such nonspecific reactions, and means to prevent them, using chymotrypsinogen and chymotrypsin as model proteins.

\section{MATERIALS AND METHODS}

\subsection{Materials}

Glycine, Z-glycine, glycine ethyl ester hydrochlorid, glycyl-DL-norleucine, L-norleucine were purchased from Sigma, St. Louis, U.S.A. Dicyclohexylcarbodiimide was obtained from Fluka AG, Switzerland, N-acetyl-L-tyrosine ethyl ester from Mann Research Laboratories, New York, U.S.A., proflavin from Nutritional Biochemicals, Corp. Cleveland, Ohio, U.S.A., Aquacide III (flake polyethylene glycol) from Calbiochem, San Diego, California, U.S.A., and hydrogen bromide from Matheson of Canada. Chymotrypsinogen $\mathrm{A}$ and chymotrypsin $\mathrm{A} \alpha$ were products of Worthington Biochemicals, Freehold, N.J., U.S.A. Other reagents were of high commercially available purity (analytical grade) and solvents were purified and/or dried according to standard procedures.

\subsection{Synthesis of $\alpha$-diazocarbonyl compounds}

\subsubsection{Diazoacetylglycine ethylester (DAG)}

Glycylglycine ethyl ester was prepared from Z-glycine and glycine ethyl ester hydrochloride by the mixed anhydride method, followed by catalytic hydrogenolysis, as described by HoFFMAN and TILAK (19). The diazotization of the free dipeptide ester was performed by the biphasic method $(30,35,43)$ yielding a yellow powder which was dried in vacuo over $\mathrm{KOH}$ pellets. Yield: $40 \%$; m.p. range $96-102{ }^{\circ} \mathrm{C} ; \lambda_{\max }^{\mathrm{CH} 3 \mathrm{OH}}=$ $250 \mathrm{~nm}\left(\varepsilon=19950 \mathrm{~m}^{-1} \mathrm{~cm}^{-1}\right)$.

\subsubsection{Diazoacetyl-DL-norleucine methyl ester (DL-DAN)}

Commercial glycyl-DL-norleucine was esterified as described by Rajagopalan et al. (27). Diazotization of the dipeptide ester was performed by the biphasic method $(30,35,43)$. In a typical experiment, glycyl-DL-norleucine methyl ester hydrochloride $(125 \mathrm{mg})$ was dissolved in $0.45 \mathrm{ml}$ cold $2 \mathrm{~m}$-sodium acetate. To this solution were added solid sodium nitrite $(55.4$ $\mathrm{mg}$ ) and one milliliter of methylene chloride. The biphasic mixture was acidified with glacial acetic 
acid $(25 \mu \mathrm{l})$ and thoroughly mixed. After standing for one hour at approx. $4^{\circ} \mathrm{C}$, the layers were separated and the aqueous phase was washed twice with one milliliter methylene chloride. The combined organic phase was then washed twice with one milliliter cold sodium bicarbonate solution (5\%), dried with anhydrous $\mathrm{Na}_{2} \mathrm{SO}_{4}$, filtered and taken to dryness under vacuo at room temperature. The diazocarbonyl compound was obtained as a yellow oil which solidified at $-20^{\circ} \mathrm{C}$. Yield: $40 \mathrm{mg}(38 \%)$. The spectral characteristics are as follows. IR $\left(\mathrm{CHCl}_{3}\right): 2110 \mathrm{~cm}^{-1}$ (diazo group), $1745 \mathrm{~cm}^{-1}$ (carbonyl in ester), $1640 \mathrm{~cm}^{-1}$ (carbonyl in diazo ketone). $\mathrm{UV}: \lambda_{\max }^{\mathrm{CH}}{ }^{\mathrm{OH}}=250 \mathrm{~nm}\left(\varepsilon=18200 \mathrm{M}^{-1}\right.$ $\mathrm{cm}^{-1}$ ); 'H-NMR $\left(\mathrm{CDCl}_{3}\right)$ : $\delta=0.9-1.8(9) \mathrm{m}$. $3.75(3) \mathrm{s}, 4.9(1) \mathrm{s}, 6.2(1)$ broad singlet. The UV and IR data correspond well to those reported for other $\alpha$-diazocarbonyl compounds (12). This diazotization procedure is described in detail because it was noted that the product obtained by direct diazotization in aqueous solution (27) was invariably contaminated by educt (glycyl-DLnorleucine methyl ester) and/or $\alpha$-hydroxyacetyl-DL-norleucine methyl ester as reflected by a low value of $\varepsilon_{250 \mathrm{~nm}}$ for the isolated product. Furthermore, we observed that mixing of $\mathrm{Cu}^{2}+$ ions and pure DL-DAN leads to a rapid yellow precipitate, while no such reaction occurs when $\mathrm{Cu}^{2+}$ ions were mixed with contaminated DLDAN prepared by diazotization in aqueous solution. Consequently, it was found that addition of educt to the pure DL-DAN prevents the precipitation from occurring (cf. sections III and IV for further details pertaining to these observations).

\subsubsection{Diazoacetyl-L-norleucine methyl ester ( $L$ - $D A N)$}

This compound was prepared from $\mathrm{HBr} \cdot \mathrm{H}$ -Gly-L-Nle-OMe by the diazotization method described above. Its spectral properties were identical with those of DL-DAN.

$\mathrm{HBr}$ - H-Gly-L-Nle-OMe was synthesized from Z-glycine and L-norleucine according to standard methods of peptide synthesis (44). Overall yield was $15 \%$ (relative to $\mathrm{Z}$-glycine). M.p. $145-148{ }^{\circ} \mathrm{C}$ (crystallized from ether/ methanol; approx. 9:1). TLC on Silica Gel in nbutanol/glacial acetic acid/water/5\% ammo- nia/acetone $(9: 2: 4: 2: 3)$ revealed a strong yellow spot (hydrobromide, $\mathrm{R}_{\mathrm{f}}=0.69$ ) and a weak pink spot (free amine, $R_{f}=0.80$ ). Spots were located using the ninhydrin reagent.

\subsection{General methods}

Melting points are uncorrected and were determined on a Fischer-Johns melting point apparatus. Ultraviolet spectra were recorded on a Cary 14, infrared spectra on a Perkin-Elmer IR-10 and nuclear magnetic resonance spectra on a Varian T-60 spectrometer.

Amino acid analysis were performed according to the method of Spackman et al. (36), with the aid of a Beckman-Spinco 120B amino acid analyzer. Samples were hydrolyzed with $5.7 \mathrm{~N}$ $\mathrm{HCl}$ for 36 hours under vacuum at $105^{\circ} \mathrm{C}$. TLC plates were developed with ninhydrin or Rydon/ Smith reagent (32).

\subsection{Assay for enzymatic activity}

The concentration of chymotrypsin in solution was determined spectrophotometrically using $\mathrm{E}_{280 \mathrm{~nm}}^{0.1 \%}=2.0$ as cited by EDELHOCH (11). Chymotryptic activity was measured with $\mathrm{N}$ acetyl-L-tyrosine ethyl ester as substrate follow ing either the titrimetric (21) or spectrophotometric (34) procedure using a Radiometer $\mathrm{pH}$-stat titrator assembly and a Cary 14 , respectively. Tryptic activation of chymotrypsinogen was achieved according to the published procedure (10).

\subsection{Chemical modification of enzyme}

Modification experiments were performed on two different scales using $0.15 \mathrm{M}$ stock solutions of diazocarbonyl reagent (in methanol) and copper(II)acetate (in water). In small scale experiments, one milliliter of a solution of chymotrypsin $\left(1 \mathrm{mg} \cdot \mathrm{ml}^{-1}\right)$ in either phosphate or acetate buffer $(50 \mathrm{~mm})$ of the desired $\mathrm{pH}$ was treated with small volumes of the reagent stock solutions which were added either in sequence or as a mixture. Thus, to achieve an enzyme:Cu${ }^{2+}:$ DAN ratio of $1: 75: 75,20 \mu \mathrm{l}$ each of copper(II)acetate and DAN were used. In some cases, reagent solutions were added repeatedly. At various time intervals, $20 \mu \mathrm{l}$ aliquots were 
removed and assayed spectrophotometrically for chymotryptic activity.

When the modified protein was to be characterized by amino acid analysis and kinetic measurements, a larger quantity of protein was modified and isolated as follows. A suitable excess of reagents (as a mixture, or in sequence) was added to $20 \mathrm{ml}$ of a solution of chymotrypsin or chymotrypsinogen $\left(1 \mathrm{mg} \cdot \mathrm{ml}^{-1}\right)$ in a 50 mm buffer of the desired $\mathrm{pH}$. The enzyme solution was precooled to $15^{\circ} \mathrm{C}$ and the reaction was performed in the dark at that temperature. Enzyme activity was tested on $20 \mu 1$ aliquots as described above. After the reaction had progressed to the desired stage of inactivation, the solution was adjusted to $\mathrm{pH} 4.0$ by the addition of $0.015 \mathrm{M}-\mathrm{HCl}$ (to destroy the unreacted reagent) and concentrated to a volume of $2-3 \mathrm{ml}$ using dialysis tubing and aquacide III. The concentrate was then applied on a Sephadex $\mathrm{G}-15$ column $(1.5 \times 30 \mathrm{~cm})$ previously equilibrated with $1 \mathrm{~mm}-\mathrm{HCl}$, which was also used for elution. The fractions containing the protein were pooled and lyophilized. In some cases the samples were rechromatographed on Sephadex G-15 in order to ensure the complete removal of all low molecular norleucine containing compounds. On the average, $70-80 \%$ of the protein initially used in the reaction with the modifying reagents could be recovered under these conditions.

\section{RESULTS}

\subsection{Effects of modifications on enzymatic activity and amino acid composition}

The effect of some $\alpha$-diazocarbonyl compounds (DAG, L-DAN and DL-DAN) on chymotrypsinogen and chymotrypsin was investigated under a variety of experimental conditions such as inclusion or exclusion of $\mathrm{Cu}^{2+}$ ions in the reaction medium, substitution of $\mathrm{Cu}^{2+}$ ions by $\mathrm{Ag}^{+}$ions and variations in the concentration of the reagents. Following recovery of the protein from the reaction mixture, its catalytic activity (or in the case of zymogen, its ability to yield an active enzyme upon activation with trypsin), as well as the amino acid composition were determined. These data are recorded in Table $\mathrm{I} . \mathrm{Cu}^{2+}$ ions, either in the presence or absence of glycyl-DL-norleucine methyl ester, exerted very little effect on the aspects of the protein mentioned above. Likewise, the diazocarbonyl compounds in the absence of $\mathrm{Cu}^{2+}$ ions had no significant influence on the activity and amino acid composition of the proteins. However, in the presence of $\mathrm{Cu}^{2+}$ ions these compounds were found to cause strong inactivation of chymotrypsin while, interestingly, in the case of chymotrypsinogen they effected only a slight decrease in the activity attainable upon tryptic activation. Examination of the protein samples following their reaction with a mixture of $\mathrm{Cu}^{2+}$ ions and diazocarbonyl compounds revealed considerable modification of tryptophan, methionine and to a lesser extent of half-cystine and tyrosine residues. Other amino acids remained unaffected. In most cases there were only traces of norleucine incorporated, indicating negligible modification of carboxylic functions under the conditions employed in these experiments. At low reagent concentration, the loss of activity noted with chymotrypsin (or of potential activity in the case of zymogen) was found to be at least partially due to an alteration in the $\mathrm{Km}$ of the enzyme for the substrate $\mathrm{N}$-acetyl-L-tyrosine ethyl ester. The Km-value determined for modified enzyme was $1.5 \mathrm{~mm}$ relative to a value of $0.7 \mathrm{~mm}$ for unmodified chymotrypsin (45). These observations are consistent with the increase in $\mathrm{Km}$ of the enzyme accompanying the oxidation of tryptophan and methionine residues $(33,42)$.

DAG effected rapid and complete inactivation of chymotrypsin. The L-isomer of DAN was more potent than the racemic mixture of the compound in its reaction with chymotrypsin. This phenomenon does not appear to be related to the stereospecific interaction of the L-isomer with the active site of the enzyme, since proflavin, known to bind at this region (4), failed to prevent the $\mathrm{Cu}^{2+} / \mathrm{L}-\mathrm{DAN}$ mediated inactivation of the enzyme. Thus, the apparent inactivation of the enzyme by this reagent appears to be mostly due to interactions with functional groups other than those at the active site of the protein. Silver ions were much less effective than $\mathrm{Cu}^{2+}$ ions in promoting inactivation of the enzyme in the presence of diazocarbonyl compounds. This is in agreement with their known ability to catalyze the Wolff rearrangement, 
F. Widmer \& T. Viswanatha: Diazocarbonyl dipeptide esters

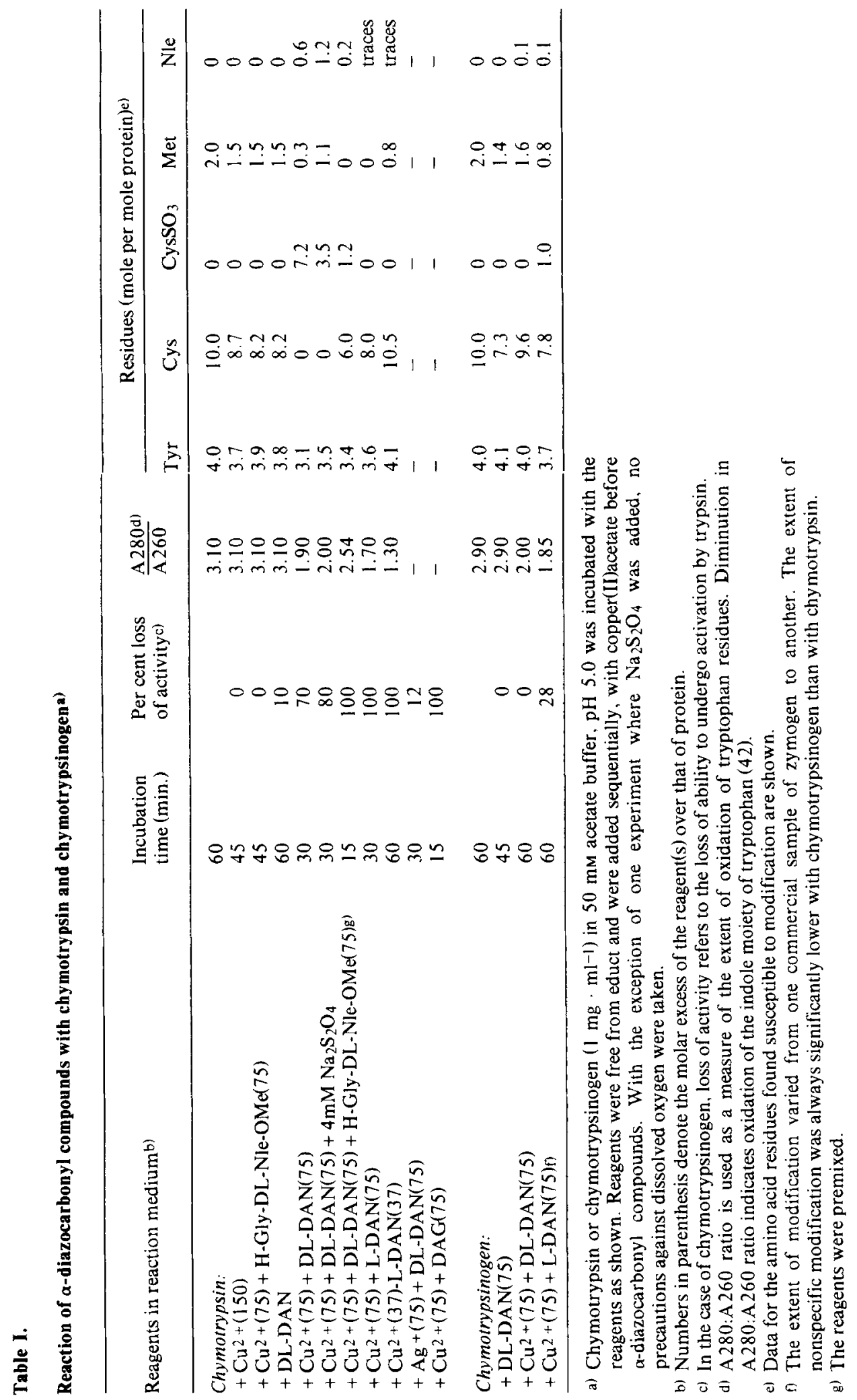


converting diazocarbonyl-derived carbenes into ketenes $(28,46)$.

The data recorded in Table I also reveal yet another significant difference in the effects mediated by the $\mathrm{L}$ - and the racemic mixture of DAN. DL-DAN in the presence of $\mathrm{Cu}^{2+}$ ions promoted extensive oxidation of cystine residues as indicated by the presence of cysteic acid (with little or no half-cystine residues) in the $\mathrm{HCl}$ hydrolysates of the modified protein. In contrast to these findings, L-DAN and $\mathrm{Cu}^{2+}$ ions failed to produce such oxidation of cystine residues, the amino acid being recovered intact in the $\mathrm{HCl}$ hydrolysates of the modified protein. The differences in the stereochemical features of the complexes of L- and D-isomers of DAN with $\mathrm{Cu}^{2+}$ ions appear responsible for the above observations.

\subsection{The role of $\mathrm{Cu}^{2+}$ ions}

The results recorded above as well as those available from the literature demonstrate a vital need for the presence of $\mathrm{Cu}^{2}+$ ions to achieve maximal modification of proteins by diazocarbonyl compounds. A review of the literature revealed a lack of concensus concerning procedure (premixing of, and/or sequence of addition of reagents) needed to achieve maximal modification. This situation, as well as the observation mentioned in section 2.2 . concerning the methods of diazotization and the purity and properties of the resulting products, prompted further investigations into the role played by $\mathrm{Cu}^{2+}$ ions in the reaction. The absorption spectra of DAN in the presence and absence of $\mathrm{Cu}^{2+}$ ions and glycyl-DL-norleucine methyl ester are shown in Figure 1. The spectrum for DAN (curve 1) is typical of that of an $\alpha$-diazocarbonyl compound and is characterized by a $\lambda_{\max }$ of $250 \mathrm{~nm}(28,46)$. The band at $250 \mathrm{~nm}$ is virtually abolished in the presence of $\mathrm{Cu}^{2+}$ ions (curve 2). This is consistent with the formation of a $\mathrm{Cu}^{2+}$ complexed carbene or with the $\mathrm{Cu}^{2+}$ ions catalyzed decomposition of $\alpha$-diazocarbonyl compounds to $\alpha$-hydroxy acids and other compounds $(17,28,46)$. Inclusion of glycyl-DL-norleucine methyl ester effectively prevented the $\mathrm{Cu}^{2+}$ ion mediated disappearence of the absorption spectra of the $\alpha$-diazocarbonyl compound (curve 3 ).

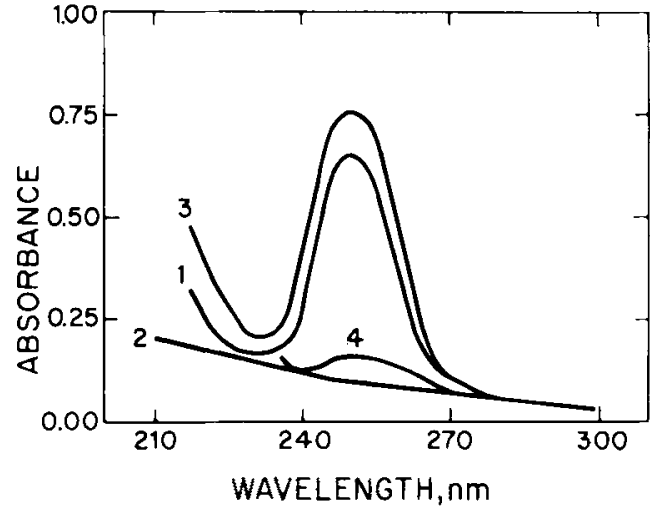

Figure 1. Absorption spectrum of L-DAN at $\mathrm{pH} 5$ in $50 \mathrm{~mm}$-phosphate buffer.

$1=\mathrm{L}-\mathrm{DAN}(30 \mu \mathrm{M}) ; 2=\mathrm{L}-\mathrm{DAN}(30 \mu \mathrm{M})$ in the presence of copper(II)acetate $(30 \mu \mathrm{M}) ; 3=$ L-DAN $(30 \mu \mathrm{M})$ in the presence of copper(II)acetate and glycyl-DL-norleucine methyl ester ( $30 \mu \mathrm{M}$ each); 4 = copper(II)acetate and glycyl-DL-norleucine methyl ester $(30 \mu \mathrm{M})$.

Treatment of pure DAN or DAG with $\mathrm{Cu}^{2+}$ ions resulted in the rapid appearance of a brownish yellow precipitate, a phenomenon that was found to be partially abolished if all solvents and buffers were repeatedly deaerated and flushed with nitrogen prior to mixing the reagents. Turbid, and/or partially precipitated mixtures of $\mathrm{Cu}^{2+}$ ions and DAN or DAG were found to be only partially effective in the inactivation of chymotrypsin, with $50 \%$ or less loss of activity being obtained in contrast to the total inactivation achieved with a clear mixture of the reagents. The formation of the precipitate was not observed with DAN or DAG preparations that were either contaminated with the parent dipeptide ester or admixed with glycylglycine methyl ester or glycyl-DL-norleucine methyl ester, presumably due to the formation of a stable trimeric complex. These observations provide a possible explanation for the discrepancy with respect to the procedure capable of producing maximum modification of acid proteases. Thus, with inhomogeneous preparations (contaminated with the parent dipeptide esters) of DAN or DAG, premixing with $\mathrm{Cu}^{2+}$ ions has little effect on the extent of modification of protein. On the other hand, with homogenous preparations of DAN or DAG, premixing will 
Table II.

Effect of $\alpha$-aminocarbonyl compounds on $\mathrm{Cu}^{2}+$ ion induced decomposition of L-DAN.a)b)

\begin{tabular}{lll}
\hline$a$-Aminocarbonyl compound & $\begin{array}{l}\text { Decomposition of } \\
\text { L-DANc) }\end{array}$ & $\begin{array}{l}\text { \% Inactivation of } \\
\text { chymotrypsind) }\end{array}$ \\
\hline Alanine & + & 0 \\
Z-alanine & + & 0 \\
N-acetyl-L-tyrosine ethyl ester & + & 0 \\
Urea & + & 0 \\
Glycyl-glycine & - & 100 \\
Glycyl-DL-norleucine methyl ester & - & 100 \\
Glycine amide & - & 100 \\
Glycine ethyl ester & - & 100 \\
Phenylalanine ethyl ester & - & 100 \\
Hydroxylamine & $+\mathrm{e}$ & 80 \\
\hline
\end{tabular}

a) These preparations were free of contamination by glycyl-L-norleucine methyl ester.

b) Similar observations were made with DAG.

c) As evidenced by the formation of a brown precipitate upon mixing of the reagents. $+=$ precipitate; $-=$ no precipitate.

d) Equimolar mixtures (75-fold molar excess over chymotrypsin) of copper(II)acetate, $\alpha$-aminocarbonyl and LDAN (in that order) were prepared and added to solutions of chymotrypsin $\left(1 \mathrm{mg} \cdot \mathrm{ml}^{-1}\right)$ in $50 \mathrm{~mm}$-phosphate buffer pH 5.0. Activity was assayed as described in section 2.

e) Weak white precipitate was formed.

result in formation of precipitate and a consequent decrease in the concentration of the reactive species. With pure preparations sequential addition of the reagents, $\mathrm{Cu}^{2+}$ ions followed by the $\alpha$-diazocarbonyl compound appears desirable. Several substances (amino acids and their derivatives) were examined for their ability to prevent the $\mathrm{Cu}^{2+}$ ion induced decomposition of diazocarbonyl compounds. Results of these experiments are shown in Table II. These studies established the minimum structural features required for the prevention of $\mathrm{Cu}^{2}+$ ion mediated decomposition of DAN of DAG. For a substance to serve as an efficient protector, it should possess an unblocked amino group and a -CO- $R$ function $(\mathrm{R} \neq \mathrm{OH})$ separated from each other by at least a single methylene group.

\section{3. $\mathrm{pH}$-range of inactivation}

Complete inactivation of chymotrypsin (as well as acid proteases reported in the literature), besides being dependent on relatively large excess of $\alpha$-diazocarbonyl compounds and $\mathrm{Cu}^{2+}$ ions, occurs only over a narrow $\mathrm{pH}$-range. Maximum inactivation could only be achieved between $\mathrm{pH}$

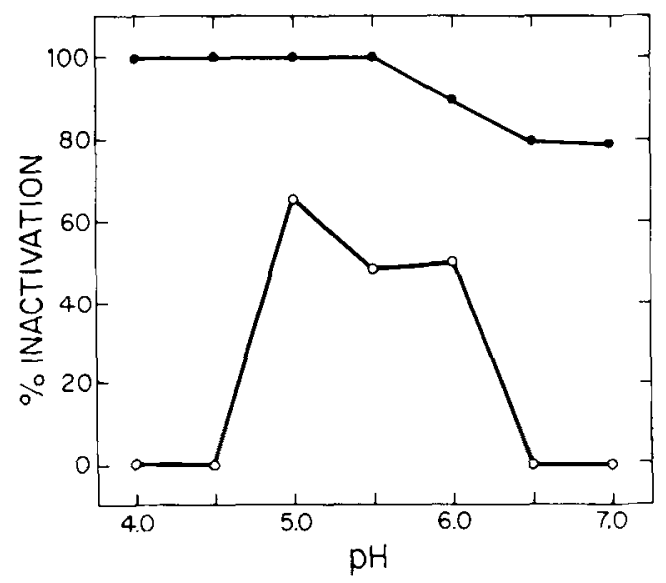

Figure 2. The effect of $\mathrm{pH}$ on the inactivation of chymotrypsin by DL-DAN in the presence of $\mathrm{Cu}^{2}+$ ions and glycyl-glycine ethyl ester.

Sodium acetate and phosphate buffers $(50 \mathrm{~mm})$ were used. O-O, activity at $30 \mathrm{~min}$ after the addition of a 75 -fold molar excess each of $\mathrm{Cu}^{2}+$ and DL-DAN (in that order) to the enzyme solution ( $1 \mathrm{mg}$ $\mathrm{ml}^{-1}$ ). - activity at $15 \mathrm{~min}$ after the addition of a solution prepared by mixing equal volumes of copper(II)acetate, glycyl-glycine ethyl ester and DLDAN (in that order) to the enzyme. The molar excess of each reagent over the enzyme was 75 -fold. 
5.0 and 6.0 (Fig. 2). The instability of $\alpha$ diazoketones below $\mathrm{pH} 5.0$ and the tendency of $\mathrm{Cu}(\mathrm{OH})_{2}$ to precipitate above $\mathrm{pH} 6.0$ dictate the $\mathrm{pH}$ range over which modifications can be performed. In view of the ability of certain $\alpha$ aminocarbonyl compounds to prevent the $\mathrm{Cu}^{2+}$ ion mediated decomposition of DAN (cf. Table II), and to form a reactive trimeric complex, their effect on the $\mathrm{pH}$ range of inactivation was investigated. As shown in Fig. 2, inclusion of a dipeptide ester in the reaction medium results in an expansion of the $\mathrm{pH}$-range over which the enzyme could be modified. Similar results were obtained with other $\alpha$-aminocarbonyl compounds listed in Table II. Thus, in the presence of such $\mathrm{Cu}^{2+}$ chelators, the $\mathrm{Cu}^{2+} / \alpha$-diazocarbonyl reagent can be employed over the range of $\mathrm{pH} 4$ to 7. This could possibly widen the scope of this reagent for chemical modification of proteins.

\subsection{Exclusion of oxygen}

The reaction of the $\mathrm{Cu}^{2+} / \alpha$-diazocarbonyl reagents with chymotrypsin or chymotrypsinogen was always accompanied by the oxidation of methionine, tryptophan and, to a lesser extent, of tyrosine and cystine residues, suggesting the participation of oxygen in the process. Furthermore, oxygen appears to be involved in the precipitation noted in solutions containing $\mathrm{Cu}^{2+}$ ions and homogeneous diazoketones. In light of these observations the effect of sodiumdithionite, $\mathrm{Na}_{2} \mathrm{~S}_{2} \mathrm{O}_{4}$, an effective oxygen scavenger (26), on the $\mathrm{Cu}^{2}+/ \mathrm{DAN}$ induced modification of protein was investigated. The reaction of a 75 -fold excess of $\mathrm{Cu}^{2+} / \mathrm{DL}-\mathrm{DAN}$ reagent with chymotrypsin $\left(1 \mathrm{mg} \cdot \mathrm{ml}^{-1}\right)$ at $\mathrm{pH} 5$ in the presence of $\mathrm{Na}_{2} \mathrm{~S}_{2} \mathrm{O}_{4}$ $(4 \mathrm{mM})$ did not result in the usual formation of brownish precipitate (at concentrations lower than $4 \mathrm{~mm}, \mathrm{Na}_{2} \mathrm{~S}_{2} \mathrm{O}_{4}$ was ineffective in preventing such decomposition of reagent). Under these conditions, nearly $80 \%$ af activity was lost after 30 minutes of reaction and the isolated protein exhibited an optical density $280 \mathrm{~nm}: 260 \mathrm{~nm}$ ratio of 2.0 (3.1 for native chymotrypsin) indicating some destruction of tryptophan. Amino acid analysis of the modified protein revealed a diminished oxidation of methionine and cystine residues and incorporation of 1.2 norleucines per mole of protein. However, the recovery of cystine residues in the $\mathrm{HCl}$ hydrolysates of the modified protein was low. It thus appears that $\mathrm{Cu}^{2}+/$ DL-DAN reacts with disulfide bonds (28, 46) in an oxygen-independent reaction which can partially be prevented by addition of the educt, i.e. glycyl-DL-norleucine methyl ester. The exact nature of this modification is subject of further investigations. Our observations indicate that exclusion of oxygen in modification reactions with $\mathrm{Cu}^{2+} / \alpha$-diazocarbonyl reagents is advantageous in so far as it reduces the nonspecific oxidative destruction of amino acid residues in the proteins. Exclusion of oxygen also prevents destruction of the reagent per se, a feature that would allow the modification reactions to be performed at lower molar excesses of reagents over protein.

\section{DISCUSSION}

$\alpha$-diazocarbonyl compounds in conjunction with $\mathrm{Cu}^{2+}$ ions have been widely employed to selectively modify carboxyl function(s) of the active site of acid proteases $(2,8,20,23,24,25$, $27,29,37-41)$. Relatively large molar excess of the reagent over that of the protein to be modified are normally employed. While the lability of the $\alpha$-diazocarbonyl compounds in the presence of $\mathrm{Cu}^{2+}$ ions, especially at low $\mathrm{pH}$, may necessitate the use of large excess of reagents, such conditions could also result in a nonspecific modification of catalytically unessential functional groups and consequent perturbation of the active conformation of the protein. The current study was undertaken: 1) to assess the nature of possible nonspecific modifications caused by $\mathrm{Cu}^{2+}$ /diazocarbonyl reagents, 2) to find conditions for the minimization of any such nonspecific modifications and 3) to establish conditions capable of preventing $\mathrm{Cu}^{2}+$ ion induced decomposition of diazocarbonyl compounds. Chymotrypsinogen and chymotrypsin were selected as model proteins in view of the extensive information available concerning their physico-chemical properties.

Neither an $\alpha$-diazocarbonyl compound (LDAN,DL-DAN or DAG) nor $\mathrm{Cu}^{2+}$ ions alone showed any effect on the activity (potential activity in the case of zymogen) of these two proteins. However, exposure of chymotrypsin to a 75 -fold molar excess of a $\mathrm{Cu}^{2+} / \mathrm{DAN}$ mixture resulted in the oxidative destruction of trypto- 
phan, methionine, tyrosine and, to a lesser extent, of cystine residues with concomitant loss of catalytic activity. The requirement for $\mathrm{Cu}^{2+}$ ions to achieve the modification of proteins has been attributed (25) to the ability of these ions to complex, and thus stabilize, the reactive carbene (II) (cf. Scheme 1) and prevent its conversion to the ketene (III) via Wolf rearrangement. Indeed, $\mathrm{Ag}^{+}$ions which promote this rearrangement $(28,46)$ were found to be much less effective than $\mathrm{Cu}^{2+}$ ions in the current as well as in other studies $(2,8,20,23,24,25,27,29,37-41)$. Only trace amounts of norleucine were incorporated in the presence of $\mathrm{Ag}^{+}$ions.

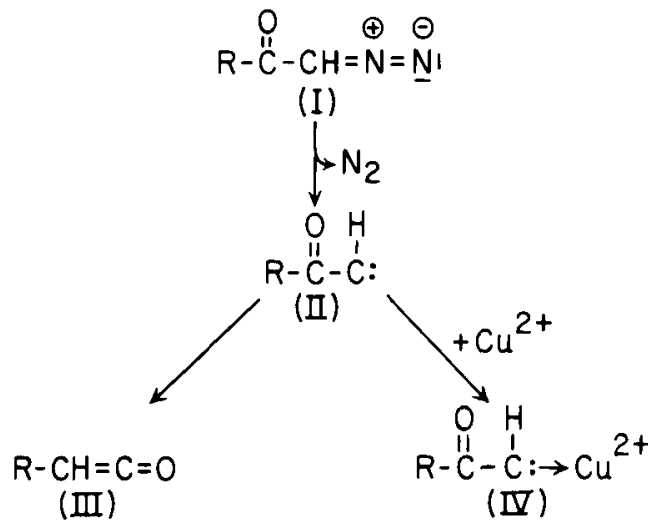

Scheme 1. Formation of $\alpha$-diazocarbonyl derived carbenes(II) and their conversion to ketenes (III) (Wolff rearrangement) or $\mathrm{Cu}^{2}+$-complexed carbenes (IV).

In the course of these modifications the appearance of turbidity, followed by a brown precipitate, indicated considerable reagent destruction rendering it difficult to assess the effective in situ concentration of the active reagent. It is also likely that certain transient intermediates resulting from the reagent destruction are actually responsible for oxidative side reactions. The fact that such precipitate formation is not always observed has led to ambiguities concerning the experimental procedure (premixing, order of sequential addition) for the use of $\mathrm{Cu}^{2+} / \alpha$-diazocarbonyl reagents, Some of our observations indicate that the basis for these discrepancies lies in the purity of the $\alpha$ diazocarbonyl compounds employed. In our hands, these side reactions always occurred when pure diazocarbonyls were used. No such precipitate was observed with inhomogeneous preparations (contaminated with starting dipeptide ester) or with pure preparations to which the parent dipeptide ester had been added. However, even when, advertently or inadvertently, employing such trimeric mixtures, the possibility for oxidative side reactions is not eliminated since the ability of a combination of $\mathrm{Cu}^{2+}$ ions, oxygen and a primary amine to act as powerful oxidant is well established $(22,31)$. However, such oxidative destruction of amino acid residues can be minimized by exclusion of oxygen from the reaction medium, a condition that can be achieved by thorough deaeration of all solvent and addition of oxygen scavengers such as $\mathrm{Na}_{2} \mathrm{~S}_{2} \mathrm{O}_{4}$.

\section{ACKNOWLEDGEMENTS}

These investigations were supported by the National Scientific and Engineering Research Council of Canada. The authors wish to express their gratitude to Professor M. OTtesen for his constructive criticisms and valuable discussions during the preparation of this manuscript.

\section{REFERENCES}

1. A boderin, A. A. \& J. S. Fruton: Inactivation of chymotrypsin by diphenyldiazomethane. Proc. Nat. Acad. Sci. 56, 1252-1258 (1966)

2. Bayliss, R. S., J. R. KNowles \& G. B. WYBRANDT: An aspartic acid residue at the active site of pepsin. Biochem. J. 113, 377-386 (1969)

3. Bayley, H. \& J. R. Knowles: Photoaffinity labeling. In: Methods in Enzymology. W. B. Jakoby, M. Wilchek, eds., Academic Press, New York, Vol. 46, pp. 69-114 (1977)

4. Bernhard, S. A., B. F. Lee \& Z. H. Tashitan: On the interaction of the active site of $\alpha$ chymotrypsin with chromophores: Proflavin binding and enzyme conformation during catalysis. J. Mol. Biol. 18, 405-420 (1966)

5. Chowdhry, V., R. Vaughan \& F. H. WesthelMER: 2-Diazo-3,3,3-trifluoropropionyl chloride: Reagent for photoaffinity labeling. Proc. Nat. Acad. Sci. 73, 1406-1408 (1976)

6. Clement, G. E.: Catalytic activity of Pepsin. In: Progress Bioorg. Chem., E. T. Kaiser, F. J. Kézdy eds., John Wiley, New York, Vol. 2, pp. 178-238 (1973) 
7. Dawid, I. B., T. C. French \& J. M. Buchanan: Azaserine-reactive sulfhydryl group of 2-Formamido-N-ribosylacetamide 5'-Phosphate: L-glutamine Amido ligase. J. Biol. Chem. 238, 21782185 (1963)

8. Delpierre, G. R. \& J. S. Fruton: Specific inactivation of pepsin by a diazo ketone. Proc. Nat. Acad. Sci., 56, 1817-1822 (1966)

9. Doscher, M. S. \& P. E. Wilcox: Chemical derivatives of a-chymotrypsinogen. IV. A comparison of the reactions of $\alpha$-chymotrypsinogen and of simple carboxylic acids with diazoacetamide. J. Biol. Chem. 236, 1328-1337 (1961)

10. Dreyer, W. J. \& H. Neurath: The activation of chymotrypsinogen. J. Am. Chem. Soc. 77, 814815 (1955)

11. ЕреLносн, $\mathrm{H}_{::}$Spectroscopic determination of tryptophan and tyrosine in proteins. Biochemistry, 6, 1948-1954 (1967)

12. Frank, F. \& R. Schwyzer: Diazoacetyl choline bromide. Experientia 26, 1207-1209 (1970)

13. Fruton, J. S.: The mechanism of the catalytic action of pepsin and related acid proteinases. In: Advances in Enzymology. A. Meister, ed., John Wiley, New York, Vol. 44, pp. 1-36 (1976)

14. Fry, K. T., O. Kim, J. Spona \& G. A. Hamilton: Site of reaction of a specific diazo inactivator of pepsin. Biochemistry, 9, 4624-4632 (1970)

15. Glazer, A. N., R. J. Delange \& D. S. Sigman: Chemical modification of proteins. In: Laboratory Techniques in Biochemistry and Molecular Biology. T. S. Work, T. Work, eds., NorthHolland, Amsterdam, Vol 4, pp. 1-206 (1976)

16. HartmanN, S. C.: The interaction of 6-diazo-5oxo-L-norleucine with phosphoribosyl pyrophosphate amidotransferase. J. Biol. Chem. 238, 3036-3047 (1963)

17. Haupter, F. \& A. Pucek: Ueber die kupferkatalysierte Zersetzung von Diazoketonen in wässriger Lösung. Chem. Ber. 93, 249-252 (1960)

18. Heinrikson, R. L. \& K. J. Kramer: Recent advances in the chemical modification and covalent structural analysis of proteins. In: Progress Bioorg. Chem. E. T. Kaiser, F. J. Kézdy eds., John Wiley, New York, Vol. 3, pp. 141-250. (1974)

19. Hofmann, J. A. \& M. A. Tilak: The successful synthesis of glycyl-glycyl dipeptide bonds via the excess mixed anhydride method. Org. Prep. Proc. Int. 7, 215-219 (1975)

20. Inagami, T., K. Misono \& A. M. Michelakis: Definitive evidence for similarity in the active site of renin and acidic protease. Biochem. Biophys. Res. Comm. 56, 503-509 (1974)

21. Jacobson, C. F., J. Léonis, K. LinderstrømLang \& M. OtTesen: The pH-stat and its use in biochemistry. In: Meth. Biochem. Analysis. D. Glick, ed., Interscience Publishers, New York, Vol. 4, pp. 171-210 (1957)

22. Jallabert, C. \& H. Riviere: Activation of molecular oxygen by monovalent copper salts: rearrangement of alcohols into aldehydes by the cuprous chloride/amine/oxygen system. Tetrahedron Letters, 1215-1218 (1977)

23. KaehN, K., M. Morr \& M. R. Kula: Inhibition of the acid proteinase from Neurospora crassa by diazoacetyl-DL-norleucine methyl ester, 1,2epoxy-3-(4-nitrophenoxy) propane and pepstatin. Z. Physiol. Chem. 360, 791-794 (1979)

24. Kellová, H.: Inhibition of cathepsin D by diazoacetylnorleucine methyl ester. FEBS-Letters, 6, 312-314 (1970)

25. Lundblad, R. L. \& W. H. Stein: On the reaction of diazoacetyl compounds with pepsin. J. Biol. Chem. 244, 154-160 (1969)

26. Meighen, E. A. \& J. W. Hastings: Binding site determination from kinetic data. Reduced flavin mononucleotide binding to bacterial luciferase. J. Biol. Chem. 246, 7666-7674 (1971)

27. Rajagopalan T. G., W. H. Stein \& S. Moore: The inactivation of pepsin by diazoacetylnorleucine methyl ester. J. Biol. Chem. 241, 42954297 (1966)

28. Regitz, M., J. K. Korobitsyna \& L. L. Rodina: Aliphatic diazo compounds. In: Methodicum Chimicum. F. Zymalkowski, ed., Academic Press, New York, Vol. 6, pp. 205-300 (1975)

29. Rickert, W. S. \& P. A. MCBride-W ARREN: Structural and functional determinants of Mucor Meihei Protease. VI. Inactivation of the enzyme by diazoacetyl norleucine methyl ester, pepstatin and 1,2-epoxy-3-(p-nitrophenoxy)propane. Biochem. Biophys. Acta, 480, 262-274 (1977)

30. Rienm, J. P. \& H. A. Scheraga: Structural studies of ribonuclease. XVII. A reactive carboxyl group in ribonuclease. Biochemistry, 4 , 772-782 (1965)

31. Rogić, M. M., T. R. Demmin \& W. B. Hammond: Cleavage of carbon-carbon bonds. Copper(II) -induced oxygenolysis of o-quinones, catechols and phenols. J. Am. Chem. Soc. 98, 7441-7443 (1976)

32. Rydon, H. N. \& P. W. G. Smith: A new method for the detection of peptides and similar compounds on paper chromatograms. Nature 169 , 922-923 (1952)

33. Lawson, W. B. \& H. J. Schramm: Modification of methionine residue near the active site of chymotrypsin by p-nitrophenyl bromacetyl-Daminoisobutyrate. Biochemistry, 4, 377-386 (1965)

34. Schwert, G. W. \& Y. TakenaKa: A spectropho- 
tometric determination of trypsin and chymotrypsin. Biochim. Biophys. Acta, 16, 570-575 (1955)

35. Searle, N. E.: Ethyl diazoacetate. Org. Synthesis, 36, 25-28 (1956)

36. Spackman, D. H., W. H. Stein \& S. Moore: Automatic recording apparatus for use in the chromatography of amino acids. Anal. Chem. 30, 1190-1206 (1958)

37. SteIN, W. H.: Chemical studies on purified pepsin. In: Structure-Function Relationships of Proteolytic Enzymes. P. Desnuelle, H. Neurath, and M. Ottesen, eds., Munksgaard, Copenhagen, pp. 253-260 (1970)

38. Takahashi, K. \& W. J. Chang: The structure and function of acid proteases. V. Comparative studies on the specific inhibition of acid proteases by diazoacetyl-DL-norleucine methyl ester, 1,2epoxy-3-(p-nitrophenoxy) propane and pepstain. J. Biochem, 80, 497-506 (1976)

39. Takahashi, K., W. J. Chang \& K. Arima: The structure and function of acid proteases. IV. Inactivation of the acid protease from $M u c o s$ pusillus by acid protease specific inhibitors. J. Biochem. 80, 61-67 (1976)
40. TANG, J.: Specific and irreversible inactivation of pepsin by substrate like epoxides. J. Biol. Chem. 246, 4510-4517 (1971)

41. TANG, J.: Pepsin and pepsinogen: models for carboxyl (acid) proteases and their zymogens. Trends Biochem. Sci. 1, 205-208 (1976)

42. Viswanatha, T. \& W. B. Lawson: The action of N-bromosuccinimide on chymotrypsin. Arch. Biochem. Biophys. 93, 128-134 (1961)

43. Womack, E. B. \& A. B. Nelson: Ethyldiazoacetate. Org. Synthesis, Coll. Vol. 3, 392-393 (1955)

44. Wünsch, K.: Synthese von Peptiden. Methoden der Organischen Chemie (Houben-Weyl-Müller eds.), Thieme, Stuttgart, Bd. XV/1 + 2 (1974)

45. Zerner, B. \& M. L. Bender: The kinetic consequences of the acyl-enzyme mechanism for the reactions of specific substrates with chymotrypsin. J. Am. Chem. Soc. 86, 3669-3674 (1964)

46. Zollinger, H. L.: Azo and Diazo Chemistry. Interscience Publishers, New York, pp. 68-123 (1961) 